\title{
パラコート中毒における生命予後と動脈血ガス分析
}

\author{
大城 義 之*1,2 佐々木 環*2 玉 井 仁*3 進 藤 亭*3 \\ 堅 村 信 介*2 大澤 源 吾*4 柏 原 直 樹*2 \\ さとう記念病院*1 川崎医科大学腎臓内科*2 市立宇和島病院内科*3 川崎医療福祉大学*4
}

key words：パラコート中毒，生命予後，動脈血ガス分析

〈要旨〉

パラコート中毒は，血液浄化法を含む様々な治療を行ってもいまだに救命率が高くない. 市立宇和島病院で 1989 年から 1996 年に経験したパラコート中毒 12 例に対し, 治療施行前に測定した動脈血ガス分析の結果が予後判定の 指標になるかどうかを生存群と死亡群に分けて比較検討を行った. 死亡群では生存群に比較し, $\mathrm{HCO}_{3}{ }^{-}$, base excess は有意に低く代謝性アシドーシスの存在が救命率の低下に関与していた。パラコート中毒の予後予測に, 動脈血ガ ス分析は簡便かつ有用な方法と考えられた。

\section{The relationship between arterial blood gas analysis and prognosis in paraquat poisoning}

Yoshiyuki Jyo-Oshiro*1,2, Tamaki Sasaki*2, Hitoshi Tamai*3, Toru Shindo*3, Shinsuke Nomura*2, Gengo Osawa*4, Naoki Kashihara*2

Satou Memorial Hospital ${ }^{* 1}$; Division of Nephrology, Department of Medicine, Kawasaki Medical School ${ }^{* 2}$; Department of Medicine, Uwajima City Hospital ${ }^{* 3}$; Kawasaki University of Medical Welfare*4

The prognosis of paraquat poisoning is poor despite various treatments. Measurement of the plasma paraquat concentration is useful to determine the prognosis, but this measurement cannot be performed at all hospitals. In this study, the relationship between arterial blood gas analysis and the prognosis in paraquat poisoning was analyzed in 12 cases at Uwajima City Hospital between 1989 and 1996 . The survival group $(n=4)$ showed higher $\mathrm{HCO}_{3}{ }^{-}$and base excess levels than the fatal group. Patients in the fatal group $(n=8)$ were in a state of metabolic acidosis. We demonstrated that arterial blood gas analysis is an easy and useful method to make a prognostic judgement of paraquat poisoning.

\section{緒言}

パラコートは，除草効果の優れた農薬として販売さ れている。しかし，人体に対する毒性は強く，経口あ るいは経皮的に吸収された場合, 死亡率は極めて高い。 また，パラコート中毒の生命予後は, 治療開始までの 時間とその時の血清パラコート濃度で判別できるとさ れている1が，現実的に血清パラコート定量が迅速に 行える施設は少ない.今回我々は，どこの施設でも簡 便に行える動脈血ガス分析に注目し，来院時すなるち 血液吸着療法 (direct hemoperfusion, DHP) 施行前
の動脈血ガス分析値と生命予後との相関関係について 検討を行った。

\section{I. 対 象}

1989 年 1 月から 1996 年 12 月までに市立宇和島病 院を受診したパラコート中毒患者で, DHP 施行前に 動脈血ガス分析および胃洗浄を行った男性 10 名, 女性 2 名, 平均年齢 57.0 歳 (28〜83 歳)を対象とした. 診 断は，尿中パラコート定性陽性をもってパラコート中 毒患者とした。

\section{大城 義之 さとう記念病院 テ 709-4312 岡山県勝田郡勝央町黒土 45 (0868-38-6688)}

Yoshiyuki Jyo-Oshiro Fax 0868-38-6693 
表 1 動脈血ガス分析値, 血清 $\mathrm{K}$ 値および血清 $\mathrm{Cr}$ 値と予後

\begin{tabular}{lcrc}
\hline & $\begin{array}{c}\text { 生存群 } \\
(\mathrm{n}=4)\end{array}$ & \multicolumn{1}{c}{$\begin{array}{c}\text { 死亡群 } \\
(\mathrm{n}=8)\end{array}$} & 検定結果 \\
\hline $\mathrm{pH}$ & $7.43 \pm 0.04$ & $7.38 \pm 0.05$ & $\mathrm{NS}$ \\
$\mathrm{PO}_{2}(\mathrm{mmHg})$ & $84.8 \pm 6.40$ & $75.9 \pm 13.2$ & $\mathrm{NS}$ \\
$\mathrm{PCO}_{2}(\mathrm{mmHg})$ & $40.8 \pm 2.99$ & $27.8 \pm 7.01$ & $\mathrm{p}<0.01$ \\
$\mathrm{HCO}_{3}-(\mathrm{mEq} / l)$ & $27.3 \pm 2.22$ & $16.9 \pm 4.55$ & $\mathrm{p}<0.01$ \\
$\mathrm{BE}(\mathrm{mEq} / l)$ & $3.50 \pm 3.00$ & $-6.00 \pm 4.04$ & $\mathrm{p}<0.05$ \\
$\mathrm{~K}(\mathrm{mEq} / l)$ & $4.05 \pm 0.44$ & $3.01 \pm 0.58$ & $\mathrm{p}<0.05$ \\
$\mathrm{Cr}(\mathrm{mg} / \mathrm{d} l)$ & $0.70 \pm 0.14$ & $0.99 \pm 0.45$ & $\mathrm{NS}$ \\
\hline
\end{tabular}

表 2 その他の因子と予後

\begin{tabular}{lccc}
\hline & $\begin{array}{c}\text { 生存群 } \\
(\mathrm{n}=4)\end{array}$ & $\begin{array}{c}\text { 死亡群 } \\
(\mathrm{n}=8)\end{array}$ & 検定結果 \\
\hline 年齢 & $47.3 \pm 9.32$ & $61.9 \pm 20.5$ & $\mathrm{NS}$ \\
尿中定性 & $2.25 \pm 1.50$ & $3.25 \pm 1.04$ & $\mathrm{NS}$ \\
胃洗浄までの時間 & $1.75 \pm 0.96$ & $2.81 \pm 2.90$ & $\mathrm{NS}$ \\
DHP までの時間 & $6.50 \pm 4.73$ & $3.94 \pm 3.13$ & $\mathrm{NS}$ \\
ステロイド使用者 & $4 / 4(100 \%)$ & $2 / 8(25 \%)$ & - \\
\hline
\end{tabular}

表 3 パラコート中毒における代謝性アシドーシスと低カリウム血症の病態

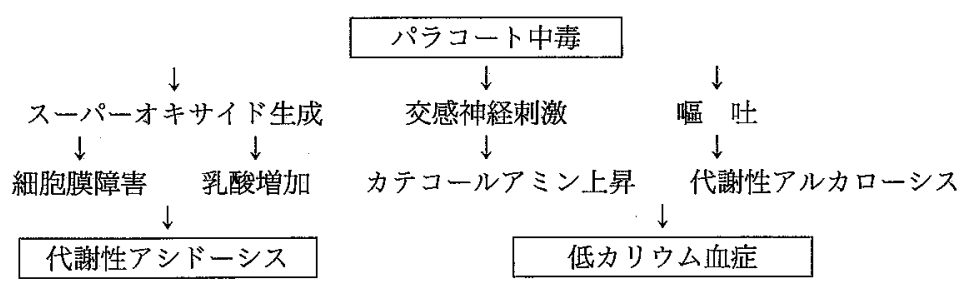

\section{II. 方 法}

対象患者それぞれについて，DHP 施行前の動脈血 ガス分析 $; \mathrm{pH}, \mathrm{PO}_{2}, \mathrm{PCO}_{2}, \mathrm{HCO}_{3}^{-}$, base excess (BE), 年齢, 血清カリウム $(\mathrm{K})$ 值, 血清クレアチニ ン $(\mathrm{Cr})$ 值, パラコート服用量, 尿中パラコート定性, DHP 施行までの時間，ステロイド使用の有無を生存 群と死亡群とで比較検討を行った．DHP はチャコー ルカラムを使用し，原則として尿中パラコート定性が 陰性となるまで行い，翋朝尿中パラコート定性が陽性 であれば陰性化するまでDHPを同様に連日施行し た.

統計学的検討は, 平均值士標準詔差にて表し, 両群 間の有意差検定は，Mann-Whitneyの $U$ 検定を用い $\mathrm{p}<0.05$ を有意な差と考えた。

\section{III. 結 果}

動脈血ガス分析の結果, 生存群 (4 名) と死亡群 (8 名）とでは $\mathrm{pH}, \mathrm{PO}_{2}$ は有意差はなかったが, $\mathrm{PCO}_{2}$, $\mathrm{HCO}_{3}{ }^{-}, \mathrm{BE}$ は死亡群ほど低く有意差を認めた. 血清 $\mathrm{K}$ 值は低いほど予後が悪い傾向を示したが，血清 Cr 值 については両群間で有意差は認めなかった（表 1 ）。

その他の因子では, 年齢, パラコート服用量, 尿中 パラコート定性, DHP 施行までの時間のいずれにつ いても, 有意差は認められなかった。 また, 生存群は 使用量は様々であったが，全例ステロイドを使用して いた（表 2 ）.

\section{IV. 考 察}

パラコート中毒の生命予後は治療開始までの時間と その時の血清パラコート濃度で判別できるとされてい る1)が，実際血清パラコート濃度を迅速に計測できる 施設は少ない. 我々は，1989 年 1 月から 1996 年 12 月 までに市立宇和島病院を受診したパラコート中毒患者 で, DHP施行前に動脈血ガス分析および胃洗浄を 行った 12 名について動脈血ガス分析と生命予後につ いて比較検討を行った，パラコート中毒の重篤症は呼 吸循環不全によるショックで，中等症では腎不全から 肺水腫による呼吸不全で死亡する，また，一時的に救 命できても，服用 1 週間を経ると肺線維症を併発しい ずれにしても呼吸不全を併発し死亡することが多 $\left(^{2 \sim 4)}\right.$.

治療は胃洗浄と下剂の投与および DHPを中心とし た血液浄化療法が行われているが，救命率は $20 \%$ 前 後 ${ }^{5 \sim 8)}$ と予後不良であり，このことはパラコートがごく 少量でも不可逆的な蔵器障害を引き起こし, 致死的と なることを表わしていると考えられる。

現在まで予後予測因子としては，血中濃度と服用時 間から判定するP Proudfoot ら いるが，現実的には血中パラコート濃度を測定できる 施設は限られており，より簡便な方法として尿中パラ コート定性から予後を推察しようという試みがなさ れ，この結果が予後予測に有用であるという報告 ${ }^{7,8)}$ が なされている.

また多因子による解析では，尿中パラコート定性の 
強陽性, 血清 $\mathrm{Cr}$ 值の上昇, 低 $\mathrm{K}$ 血症, 代謝性アシドー シスを示す場合, 極めて予後不良であるという報告9 や, 白血球数, 血清アミラーゼ値, 血清トランスアミ ナーゼ值がいずれも生存群より死亡群のほうが高值で あるという報告 ${ }^{10)}$ なされている。我々の結果におい て, 血清 $\mathrm{Cr}$ 值についてはパラコート服用後, 比較的早 期に治療を受けている症例が多いためか両群間で有意 差は認めず，年齢についても生存群と死亡群とで予後 について有意差は認められなかったが，パラコート服 用量については, 聞き取り調查のためか retrospective には服用量の不明な症例もあり十分な評価は行えず， また尿中パラコート定性，DHP 施行までの時間につ いても症例数が少ないことも関係したためか，有意差 は認められなかった。

パラコート中毒における動脈血ガス分析の結果につ いては, 吉田ら ${ }^{8)}$ は死亡群と生存群とで有意差はな かったと報告しているが，この中で代謝性アシドーシ

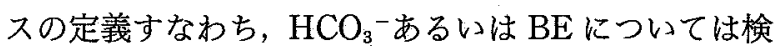
討されていない．代謝性アシドーシスの原因として， パラコートによるスーパーオキサイドの生成からの 各々の細胞膜障害による臟器障害と乳酸の増加による 機序の他, 尿細管へのパラコートによる $\mathrm{HCO}_{3}{ }^{-}$の再吸 収障害, すなわち尿細管性アシドーシス ${ }^{11}$ が考えられ， 㵴器障害を反映することから予後予測の指標となるこ とが示唆される。 また代謝性アシドーシスは急速に呼 吸性アルカローシスにより $\mathrm{pH}$ が改善されることから も $\mathrm{HCO}_{3}$ ーおよび $\mathrm{BE} に$ 注目した予後予測が望ましい と考えられ，我々の結果においても $\mathrm{PCO}_{2}$ が死亡群で 低下していることは，この代償機転によるものと考え られた。本症例のアシドーシスの機序については, 乳 酸の測定は行っていないものの，尿中ケトン体はいず れの症例でも陰性で, 血清 $\mathrm{Cr}$ 值の上昇を認めないこ とから，ケトアシドーシス，尿毒症性アシドーシスに よる可能性は否定的で，上記による機序が考えられた，

一方, 低カリウム血症はパラコート中毒に伴う嘔吐, 下痢などの消化管障害や，交感神経の緊張状態によっ て引き起こされることが報告されている12（表 3 ）。

生存例において投与方法はまちまちであるが，全例 ステロイドの投与が行われており，ステロイドがパラ コートの毒性を下げることから, 臟器障害を緩和させ る働きがある可能性が示唆された。

\section{結語}

1）市立宇和島病院におけるパラコート中毒 12 例
について動脈血ガス分析の結果に注目し予後予測を 行った.

2) 死亡群では代謝性アシドーシスを呈していた が，生存群でばその傾向はみられなかった。

3) 動脈血ガス分析はパラコート中毒の予後を推定 するうえで簡便かつ有用な方法であることが示唆され た.

謝辞：稿を終えるにあたり，データの収集に多大なる御 協力を頂きました, 市立宇和島病院長 近藤俊文先生に厚く 御礼申し上げます。

\section{文献}

1) Proudfoot AT, Stewart MS, Levitt T, Widdop B : Paraquat poisoing significance of plasma-paraquat concentrations. Lancet $2: 330-332,1979$

2) Bullivant $\mathrm{CM}:$ Accidental poisoning by paraquat: report of two cases in man. Brit Med J 1:12721273, 1996

3) Solfrank G, Mathes G, Clarmann M, Beyer KH : Haemoperfusion through activated charcoal in paraquat intoxication. Acta phamacol in paraquat intoxication. Acta Pharmacol Toxical 41(Suppl) : 91-101, 1977

4）吉田 薰, 浅野 泰, 中島逸郎, 岩間 元, 進藤靖夫, 岡本一弘, 武田和司, 照喜名重治, 生沼孝夫, 草野英 二，細田瑳一：パラコート中毒 10 症例に対する Direct Haemoperfusion の効果検討. 日腎誌 $22 ： 1001-$ 1011, 1980

5）小濱啓次：中毒一特に農薬中毒について，広島医学 $42: 613-618,1989$

6）菅 政治, 神田和哉, 过 雅士, 过村玄弘, 米田文男, 中島幹夫：パラコート中毒の臨床的検討. 西日泌 54 ： 172-175, 1992

7）宮内義浩, 斎藤陽久，伊良部徳次：当院における最近 6 年間のパラコート中毒 39 例の検討。旭中医報 14 : 24-27, 1992

8）吉田京介, 川俣泰男, 大友 晋：パラコート中毒の予 後推定について。透析会誌 $28: 145-150,1995$

9）佐藤重仁, 登内 真, 山口浩史, 内藤裕史 : パラコー 卜中毒の急性期死と来院時の検查所見. 救急医学 12 ： 1125-1129，1988

10）道本真保，藤乗嗣泰，岡 一雄，鷹觜徳子，沼部敦司， 八木 繁：パラコート中毒 36 症例の予後に関与する 因子の検討。透析会誌 $28: 139-144,1995$

11) Batlle D : Renal tubular acidosis. Med Clin North Am 67 : 859-878, 1983

12）渡辺誠治, 水谷太郎, 近藤陽一：パラコート中毒と低 カリウム血症．救急医学 $10 ： 871-879 ， 1986$ 